\title{
THE RELEVANCE OF THE CHINESE EXPERIENCE FOR THIRD WORLD ECONOMIC DEVELOPMENT
}

\author{
THOMAS E. WEISSKOPF
}

Since the mid-1970s the People's Republic of China has entered into a transitional phase of political and economic uncertainty, following its first quarter-century of development under the leadership of Mao Ze-dong. Statements and actions by the post-Mao political leadership point to the possibility that the social and economic policies characteristic of the first 25 years of the People's Republic may be considerably altered in the years to come. While it is surely too early to assess the scope of the changes that will characterize the post-Mao period, it is now appropriate to look back and assess the Chinese development experience under Mao.

This development experience has attracted a great deal of attention, especially from people elsewhere in the third world, as reports of China's substantial development achievements have contrasted with evidence of development failures in many other third world countries. Although China's current leaders tend to emphasize the backwardness of the Chinese economy relative to the rich industrialized economies of the West, China's economic progress since the triumph of the Communist Revolution in 1949 has generated much interest in the Maoist approach as a potential model for third world economic development. It is clear that the Chinese experience has been in many ways a unique one, from which other societies may have much to learn.

In this paper I will seek to determine the extent to which lessons can be drawn from the Chinese experience under Mao by people concerned with the prospects for economic development in the rest of the third world. My perspective will be very broad; I will focus on the basic institutions and elements of economic strategy which have distinguished the Chinese development model sharply from that of most other countries. Thus my discussion will be directed to people in a position to consider broad alternative approaches to development, whether they be academic scho- 
lars or participants in movements for social, political, and economic change in the third world. I will begin with a brief review and discussion of some of China's major development achievements in the quarter-century following the Revolution. Next, I will identify ten lessons in development strategy that are suggested by the Chinese experience, following which I will analyze the extent to which the applicability of these lessons is linked to conditions obtaining in the People' Republic of China, focus on the importance of the political-economic system, and consider the geographical and historical setting. Finally, I will conclude with some observations about the transferability of lessons from the Chinese experience to other parts of the third world.

\section{China's Achievements in Economic Development}

There was a time when a nation's performance in economic development was measured exclusively by the rate of growth of its per capita output. However, the experience of poor countries in recent decades has led to increasing doubt about the facile identification of economic development with economic growth. On the one hand, political leaders in many of these countries have explicitly proclaimed development objectives other than rapid economic growth, such as greater equity and national self-reliance. On the other hand, it has become evident that there are a variety of ways of promoting economic growth, each with different consequences for other aspects of economic development. To measure China's achievements in economic development, it is therefore important to consider the progress made with respect to several relevant development objectives.

Both the political rhetoric and the academic literature on economic development suggest that four broad objectives are especially compelling: faster economic growth, greater economic equity, higher rates of employment, and a greater degree of economic self-reliance. Each of these objectives in turn comprises a number of related sub-objectives, so that there exists a variety of possible performance indicators with which to measure progress over time. In spite of continuing difficulties in obtaining reliable statistical information, there is now sufficient evidence available to document reasonably accurately China's performance with respect to the four major development objectives.

Economic Growth.' Most estimates of the average annual rate of growth of total real output from the early 1950 s to the mid-1970s are close to $6 \%$, with a corresponding rate of growth of per capita output of approximately $4 \%$. Industrial output has grown especially rapidly: the estimates 
suggest a minimum of $10 \%$ per year. Agricultural output has grown more slowly, but it has outpaced the growth of population (roughly $2 \%$ per year) and may have reached an average of $3 \%$ for the period as a whole. Although the share of total output devoted to investment has risen to an unusually high level (estimated at more than $25 \%$ ), the average rate of growth of per capita consumption grew at an annual rate of at least $3 \%$ from 1950 to 1975 . These growth figures are considerably higher than average for the third world as a whole, but there are some non-socialist countries that have shown more rapid economic growth (e.g., Taiwan, South Korea, Iran, Mexico). ${ }^{2}$

Economic Equity. ${ }^{3}$ China's achievements in economic equity have contrasted dramatically with the experience of many other third world countries. First, the evidence suggests that the Chinese have succeeded in providing for virtually everyone the security of a modest but adequate minimum standard of living, including the basic necessities of food, shelter, and clothing, as well as access to health care and education. Second, the Chinese have completely elimimated the huge individual and family fortunes that in the non-socialist world permit a small elite to enjoy luxurious patterns of consumption out ef all proportion to the national average standard of living. To be sure, there remain considerable inequalities of income in contemporary China; but the Chinese have avoided the pattern of sharply increasing inequality that has most often accompanied the process of early industrialization in developing countries. Moreover, by the universal provision of certain benefits, by the subsidization and/or rationing of many necessities, and by a strong social taboo on ostentatious consumption, the Chinese have greatly mitigated the differentiating consequences of unequally distributed incomes for personal life styles and consumption patterns. The Chinese have also done very well with respect to other dimensions of economic equity. Urban/rural differentials and inter-regional disparities in levels of living have not been allowed to increase (as they have in almost every other developing country), and they may even have been reduced by centralized macroeconomic policies designed to redistribute resources and income from urban to rural areas and from richer to poorer regions. At the level of the individual enterprise (rural or urban, agricultural or non-agricultural), the Chinese have significantly reduced the high degree of economic and social stratification inherited from pre-Revolutionay China. Real differentials in remuneration are much narrower in China than almost anywhere else in the modern world, and the status distinction between workers and managers was systematically de-emphasized during Mao's lifetime. 
Employment ${ }^{4}$ Although there appears to be a considerable amount of underemployment (i.e., relatively unproductive employment) in China as in other labor-abundant countries of the third world, the evidence suggests that there has been very little overt unemployment. Not only has virtually every able-bodied man been provided with some kind of job, but growing numbers of women have entered the active labor force. China's ability to employ the bulk of the population of working age stands in stark contrast to the experience of every non-socialist country in the third world, where a significant fraction of the potential labor force is involuntarily idle.

Economic Self-Reliance. ${ }^{5}$ The objective of economic self-reliance is a broad one that includes two different but related dimensions. First, it entails the notion of economic self-sufficiency, which can be promoted by developing a diversified structure of productive capacity that minimizes dependence on goods and services imported from outside the economy in question. Second, it entails the notion of economic autonomy, which can be promoted by establishing indigenous control over economic activities and minimizing reliance on (or indebtedness to) people and institutions from outside the economy. Economic self-reliance, in the sense of selfsufficiency as well as autonomy, has been promoted as an objective at the national level as well as at the regional and local level.

China has achieved an overall degree of national self-reliance unparalleled in the third world. China's achievements in national self-sufficiency have been substantial but not unique. The Chinese economy produces a great diversity of agricultural and industrial products, including many kinds of capital goods; however, China remains dependent on imported goods and technology for relatively advanced types of industrial activity (e.g., aircraft manufacturing). China's achievements in national autonomy have been especially impressive. Economic activity is entirely under Chinese control; China has maintained a generally favorable balance of trade, has remained free of any major foreign indebtedness, and has been relatively independent of foreign financial and technical assistance, especially since the break with the Soviet Union in 1960. In addition to its degree of national self-reliance, China has made considerable progress in promoting regional and local self-reliance. Industrial activity in general has been dispersed around the country, and small-scale industries in particular - serving local markets and oriented primarily to nearby agricultural activities - have been established in large numbers in many rural areas. It is harder to measure the extent to which regions and localities have gained in economic autonomy, but most productive activities are managed by regional and local authorities. 
Viewed as a whole, the most striking feature of China's economic development performance in the first quarter-century since the Revolution is that the achievement of a very satisfactory rate of overall economic growth was combined with impressive progress with respect to several other significant objectives of economic development. China's was not the fastest-growing economy in the third world, but China was surely the nation with the most balanced pattern of economic development. The Chinese experience proves decisively that the achievement of rapid economic growth need not necessarily preclude the attainment of other development objectives such as full employment and a high degree of equity and self-reliance. This important proposition runs counter to the experience of those third world countries that have grown rapidly in the postwar period along capitalist lines. In every capitalist "success story" the distribution of income, wealth, and power remains highly unequal; problems of unemployment abound, and the role of foreigners in the economic growth process remains a very important one. ${ }^{6}$ Only in China (and perhaps to a lesser extent in North Korea and North Vietnam) has it been demonstrated that substantial economic growth can be achieved in an egalitarian social and economic environment in which employment is assured and in which both national and local self-reliance is significantly enhanced.

Establishing the possibility of rapid economic growth and the simultaneous achievement of other development objectives does not prove it can become an actuality everywhere else in the third world. Even so, the Chinese experience is significant because it demonstrates the potential of a radical socialist alternative to capitalist development and thereby sets new and higher standards for the goals of economic development. The Chinese example makes it difficult for anyone to argue convincingly that a "trickle-down" capitalist model of development, which ignores or defers consideration of equity, employment, and self-reliance, is the only or best way to promote economic progress. In recent years there has in fact been a marked shift in emphasis toward non-growth development objectives in the rhetoric (and, to a much lesser extent, in the actions) of many third world political leaders and first world development agencies. This shift is partly attributable to social and political tensions arising from the pursuit of purely growth-oriented capitalist development strategies, but it has undoubtedly been reinforced by the evidence of progress in China toward a multiplicity of development objectives. China's progress under Mao has also stimulated interest in possible lessons for other third world countries from the Chinese development experience. This possibility will be examined in the following sections.? 


\section{Lessons From the Chinese Strategy of Development}

I have asserted that the most significant implication of China's development performance is that the achievement of rapid economic growth can be combined with significant progress toward several other relevant development objectives. It follows that the strategy of economic development pursued in China should offer object lessons about the means by which this achievement can be obtained. My purpose here is to identify key elements of the Chinese development strategy. It has evolved over time, and there have been frequent modifications of economic policy since 1949. In considering the strategy here, I will confine myself to ten fundamental elements which were introduced and pursued (with varying degrees of commitment) under Mao's leadership from 1949 to $1976 .{ }^{8}$ In each case I will describe briefly the element of strategy and then discuss how it can contribute to the simultaneous promotion of economic growth and one or more other development objectives. ${ }^{9}$

\section{Promotion of Collective Institutions and Behavior Patterns. A distinc-} tive element in the Chinese strategy of development under Mao was the priority given to institutional and behavioral change in general, and the promotion of collective institutions and behavior patterns in particular. Collective institutions bring people together into a context of shared experience, cooperative effort, and participatory control; they imply a degree of equality in status and decentralization of authority that goes well beyond the replacement of private with public ownership and management. The drive toward collective institutional forms was strongest in rural areas, where the progressive transformation of agrarian society from one based on private land-holdings to one based on collective production brigades and production teams preceded major efforts to revolutionize techniques of agricultural production. But also in urban areas, many enterprises and neighborhoods were reorganized along more collective lines. The development of collective institutions was accompanied by the inculcation of collective values through the educational system, the media, etc., in a deliberate effort to change the way people think and act so as to promote more cooperative and less antagonistic patterns of behavior.

An important aspect of the Chinese promotion of collective institutions and behavior patterns was the effort to depart from conventional elitist modes of decision-making within production units by encouraging mass participation in the decision-making process. In any organization - wheth- 
er private or public - there is a tendency for those at the top of the administrative hierarchy, and/or those with the greatest expertise, to dominate in making decisions. Often this tendency is explicitly sanctioned by an authoritarian form of organizational control that relegates most people to a position of taking orders from above. But the Chinese tried to counter this elitist model by stressing the right of every peasant or worker in a production unit to participate in the decision-making process and by arranging for mass involvement in policy discussion. Whatever the actual influence of individual peasants or workers on the decisions that are ultimately made, there is little doubt that they derived a genuine sense of involvement and identification with the production unit that is conspicuously lacking in the conventional elitist model.

The emphasis on institutional and behavioral change along collective lines can contribute to greater productivity (and hence to faster economic growth) in several ways. Institutions that encourage or permit a privileged few to dominate the great majority have long been recognized as major obstacles to the diffusion of improved methods of production and to the growth of worker productivity. Systematic efforts to introduce new institutions and inculcate new patterns of behavior that stress cooperation in productive activity and the sharing of its fruits can encourage greater receptiveness to new technology and greater work effort in general. Widespread participation in decision-making is likely to enhance the productivity of an enterprise because all of its workers (rather than just a few top executives) have an incentive and an opportunity to develop an understanding of the operation of the enterprise as a whole and to make decisions about its improvement. Even more important, worker morale and productivity are bound to be higher when participation in decision-making leads to strong identification with the enterprise rather than continual antagonism toward bosses. ${ }^{10}$

At the same time, the promotion of collective institutions in general - and worker participation in decision-making in particular - can contribute to greater equity at both the national and the enterprise level. The elimination of private ownership of land and other means of production removes a major source of inequity in the national distribution of income. Moreover, the promotion of collective ideals and cooperative behavior can succeed only in an environment in which the distribution of the fruits of productive activity is reasonably equitable. Mass participation in decision-making contributes to equity at the enterprise level by reducing differentials in status and power that tend to result in corresponding differentials in income as well. Finally, the promotion of collective insti- 
tutions serves the objective of local self-reliance insofar as it tends to reduce the degree of control by central authorities and to provide more autonomy to local collectivities.

2. Maximization of Productive Labor Input. Like many other third world nations, China began its modern development effort with a relatively abundant supply of labor and chronic problems of unemployment. To assure maximum use of the potentially available labor force under such circumstances, it is necessary both to generate sufficient opportunities for productive employment (to raise the demand for labor) and to find ways of increasing the hours that people have available for work (to raise the supply of labor). In most poor nations the demand for labor has remained well below the level needed to employ everyone even without any increase in labor supply. But the Chinese succeeded in developing institutional arrangements to ensure that virtually every adult capable of working is indeed engaged on a full-time basis in some form of productive work activity.

Public authorities in China took responsibility for providing jobs to everyone able to work, who was in turn obligated to work full-time at the job to which he/she was assigned. The generation of sufficient employment opportunities in a labor-abundant society was achieved by systematic efforts to promote labor-using activities and techniques of production. On the one hand, small-scale and labor-intensive industries and service activities were promoted to complement the basic necessary large-scale and capital-intensive industries (this is known as the policy of "walking on two legs"). On the other hand, a great variety of labor-intensive public works projects were organized to employ labor at times and in places where regular employment opportunities are limited (e.g., by the seasonal nature of many agricultural activities). Indeed, the ingenuity and determination of Chinese authorities to generate work opportunities actually turned an abundance of labor into a shortage of labor in many areas.

While raising the demand for labor, the Chinese sought to increase the available supply of labor in a variety of ways. Small-scale industrial and service activities were dispersed to neighborhoods and communities where they would be more accessible to workers whose mobility is limited (e.g., by children); child-care centers were established to permit both parents to work simultaneously; certain kinds of productive work were performed by children as part of their school curriculum; and vacation time was limited by comparison with most other societies. In addition, periodic mass campaigns engaged large numbers of people in more or less 
voluntary extra work on collective tasks. This strategy of exhaustive labor mobilization obviously and directly serves to achieve the objective of full employment. In a labor-abundant economy, it also makes an important contribution to economic growth by assuring full utilization of an abundant resource. To be sure, some of the labor thus mobilized is utilized in relatively unproductive ways and might more appropriately be considered "underemployed" than fully employed. But this observation does not detract from the fact that every person enjoys the dignity of a full-time job. Nor does it alter the fact that every person is making some positive contribution to the national product; since everyone's basic subsistence requirements must be met somehow out of that national product, whether or not they are making any productive contribution, the fact that some people may in some sense be contributing less than they consume is immaterial.

3. Alternative Means of Work Motivation. The Chinese determination to maximize the quantity of labor done was complemented by vigorous efforts to stimulate greater effort and creativity on the part of the workers, based on the premise that wide variations are possible in the quality of work done by workers. It follows that motivating a worker to perform to his/her full potential can lead to great gains in overall productivity. ${ }^{11}$

The conventional means of work motivation in developed or developing economies is based primarily on individual material gain incentives, in the form of higher wages, bonuses, or profits. The Chinese strategy was not to eliminate such incentives entirely, but to de-emphasize them and to rely to a varying extent on other kinds of incentive systems. Differential wages were paid for work of different quantity and quality, but wage differentials were kept within a relatively narrow range. Wherever possible, collective rather than individual material gain incentives were stressed, so that the return for greater work effort would be realized in material gains for an entire production brigade, commune, factory, or neighborhood. And non-material incentives, involving appeals to social conscience and pride combined with strong group pressure, were an important element in the overall Chinese approach to work motivation. These were based on continuing politicization of the people by Party leaders and cadres as well as by periodic ideological campaigns to spur the accomplishment of specific tasks.

Reliance on multiple modes of work motivation, with flexibility to vary the relative emphasis on alternative modes over time, contributes to economic growth by sustaining higher levels of work effort than would be 
possible using only individual material gain incentives. Beyond effort alone, creativity and leadership at work seem more likely to be stimulated by collective and non-material incentives than by individual material gain incentives, because it is generally difficult to structure the latter in such a way as to reward directly the creative or exemplary worker. Finally, the downgrading of individual material gain incentives permits economic growth to proceed in a context of greater equity in the distribution of income because differentials in labor income can be considerably narrowed when they are no longer the primary basis for motivating work effort.

4. Mass-oriented Human Resource Development. A distinctive element in the Chinese approach to improving labor quality (or "investing in human capital" $)^{12}$ was the emphasis on distributing a modest amount of relevant skills to each of many people rather than concentrating a great amount of skills on a limited number of people. This was clearly manifested in the health field, where the Chinese devoted much of their resources to the training of para-professionals rather than professional experts. But it permeated many other fields as well - education, industry, agriculture, etc. - in a systematic effort to limit dependence on experts (and the power accruing to those experts). There are obvious limits to this approach, and there are consequently highly specialized and expert scientists, engineers, and doctors in China. But over a considerable range of choice the Chinese moved much further away from an elitist pattern of human resource development than most other societies. Such a mass-oriented human resource strategy is economically more rational (and in that sense more conductive to economic growth) than an elite-oriented approach in a poor society where skills are scarce in supply, both because the costs of imparting skills tend to be lower and the opportunities to apply the skills tend to be greater the less specialized the skills in question. At the same time, this strategy promotes equity both by distributing sources of personal power and prestige more equally among the population and by contributing to more widespread access to important social services provided by skilled personnel (such as health care and education).

5. Universal Guarantee of Material Security. The Chinese public authorities consistently took responsibility for guaranteeing a minimum level of material security to everyone in the society. Whatever an individual's ability to work or performance at work, he/she was able to count on receiving the basic necessities of life - sufficient food, clothing, and shelter to sustain a modest but essentially healthy standard of living. The real income floor thus guaranteed was gradually improved over time in quan- 
tity and quality, until it included at least some basic health care and access to primary education for everyone. The Chinese people thus enjoyed a form of comprehensive social insurance that relieved them of the threat of catastrophic economic loss.

The guarantee of material security contributes in several ways to the pace of economic growth. First, it contributes to the success of family planning efforts which (especially in a labor-abundant economy) are likely to reduce the rate of population growth more than the rate of output growth, thereby accelerating the growth of per capita output. A major obstacle to the success of family planning programs in many poor countries has been the desire of parents to have additional children as a form of insurance against economic insecurity. ${ }^{13}$ The guarantee of material security eliminates this obstacle, and the organizational apparatus necessary to provide minimal levels of health care and other basic services to everyone serves as an ideal mechanism for promoting birth control practices.

Second, the assurance of a minimum real standard of living for all contributes to the growth of output by improving the productivity of those classes of workers who would otherwise be below that minimum. ${ }^{14} \mathrm{Up}$ to levels that are enjoyed by most workers only in affluent societies, worker productivity is clearly a positive function of the level of nutrition, health, and education of the worker. Where every able-bodied person has the opportunity and the duty to work, public expenditures necessary to guarantee adequate real incomes and basic social services for people otherwise deprived of them assume the form of "human capital" investment; they contribute to enhanced output by increasing the quality of employed labor.

Third, the guarantee of material security contributes to a social climate in which people are more likely to identify their own interests with the interest of the larger collective societal unit that is the source of the guarantee. Under these circumstances, collective material incentives and moral incentives based on an appeal to pride in the society as a whole are more likely to be successful in motivating greater work effort. Moreover, the responsibility of public authorities to provide a minimum standard of living for every person irrespective of their work generates a strong incentive for those authorities to find productive work for everyone, even though this may mean that some add less to output by producing than they substract by consuming (as is often the case in poor and laborabundant economies). ${ }^{15}$ Apart from its various potential contributions to 
economic growth, the universal guarantee of material security contributes directly to a more equitable distribution of national income.

6. Restriction of Luxury Consumption. Just as the Chinese set a lower limit on people's living standards by guaranteeing a minimum level of material security, so they imposed an upper limit by restricting luxury consumption. This restriction was accomplished partly by limiting the maximum level of individual incomes and partly by limiting the availability of luxury consumption goods and services. The domestic consumer good sector was heavily oriented to the production of necessities; the few luxury items actually produced were destined primarily for export (or for visiting foreigners). Similarly, the import of luxury goods was virtually banned. General tolerance of such consumption limitations was fostered by the minimization of contact with more affluent life styles in foreign countries.

The restriction of luxury consumption can contribute to economic growth in two ways. First, it can facilitate a higher rate of investment and more rapid new capital formation, for resources that might otherwise be devoted to luxury goods production are instead available for the production of capital goods. Second, it may increase the net availability of scarce resources such as capital equipment and foreign exchange, for many luxury goods are relatively capital- and import-intensive as compared with other consumption or investment goods. ${ }^{16}$ Finally, like the universal guarantee of material security, the restriction of luxury consumption contributes directly to the objective of equity in the national distribution of economic well-being. But, in addition, it contributes significantly to economic equity at the enterprise level by reducing differences in life styles among workers at different levels of authority and income.

7. Reduction of the Social Division of Labor. Economic organization in most modern societies fosters a high degree of specialization by task; indeed, the more differentiated the occupational structure of a society's labor force, the more advanced its economy is likely to be considered. In this respect, too, the Chinese experience under Mao was distinctive in its periodic concern with encouraging individual workers to engage in a variety of different kinds of tasks rather than develop systematically only one kind of specialized competence. Thus the Chinese required many "mental" workers to undertake manual labor for various periods of time, they sought to include the experience of manual labor with the acquisition of cognitive skills in the educational system, and they encouraged 
manual workers and peasants to participate in managerial decision-making. All of this can be described as an attempt to reduce the social division of labor as opposed to the technical division of labor, for it seeks not to counter the technical division of production processes into many separately performed sub-tasks but to counter the social allocation of a single kind of productive role to each person throughout his/her productive life.

The division of labor has long been regarded as the most important basis for advances in productivity. However, the productivity gains to be reaped from the specialization of tasks - the technical division of labor - do not always require the continual specialization of individuals to tasks the social division of labor. In cases where long and arduous training is required to master a particular kind of task (e.g., advanced medical practice), it would undoubtedly be wasteful to rotate people in and out of the occupation for limited amounts of time. But in many instances where the requisite training is more easily acquired, the efficiency losses associated with occupational turnover could well be more than offset by productivity gains from several other sources. These include greater alertness due to the reduced monotony of work, more innovative ideas because of greater variety in the past experiences and perspectives of workers, and better communication and understanding among workers engaged in different tasks, because of a larger degree of shared background and experience. Thus, efforts to reduce the social division of labor may in many instances pay off in terms of greater productivity and more rapid economic growth. At the same time, they contribute to greater equity both at the enterprise and national level: they tend to equalize status, prestige, and power among different kinds of workers in any given work setting, and they encourage a more equal overall distribution of income and power by distributing skills and roles more evenly across the whole population.

8. Economic Diversification of Regions and Localities. Just as the Chinese sought to reduce occupational specialization, thereby enabling people to become more diversified in experience, so they sought to reduce the economic specialization of geographical areas, thereby enabling regions and localities to become more diversified in economic capacity. This strategy of economic diversification was carried out at several levels. First, it included spreading new units of major industries into many different provinces rather than concentrating all units in a few initial or most favorable sites. Second, it included the establishment of small-scale industrial enterprises in towns and rural areas throughout the country, as 
part of a concerted effort at rural industrialization. Third, it involved a systematic attempt at the commune level to integrate agricultural production with related industrial development activities - production and repair of agricultural implements, processing of agricultural products, and construction of roads and water works.

All such policies of economic diversification clearly serve the development objective of promoting greater economic self-reliance at the regional and local levels, Insofar as they involve geographic dispersal rather than concentration of key industries, they also contribute to greater equity among regions. More controversial is the contention that the economic diversification of regions and localities serves the objective of promoting more rapid economic growth, for it runs counter to the (neoclassical) economic logic of specialization by comparative advantage. Yet there are certain important benefits attributable to the spread of industry to rural areas and/or to small-scale establishments which may outweigh any costs associated with less-than-optimal sites for plants or scales of production. ${ }^{17}$ In the first place, rural and small-scale industrialization helps to develop the technical skills and know-how of much larger numbers of people than would be possible when industry is concentrated in urban areas and large units. Equally significant, a decentralized structure of industry permits much greater flexibility in adapting to local resource supply conditions. In particular, small-scale and/or rural industry is likely to be more compatible with the relatively labor-intensive and capitalsaving techniques of production that are most appropriate for poor and labor-abundant economies. Finally, foregone economies of large-scale production may be offset by lowered costs of transport and distribution.

9. Rural-Urban Balance. One of the most persistent patterns characterizing the development experience of third world nations is a marked prourban bias. This bias is reflected in many spheres: allocation of development expenditures, distribution of medical and educational facilities, and policies affecting the terms of trade between rural and urban products. Consequently, urban real incomes tend to be higher and to grow faster than rural real incomes, and there is a great deal of migration from rural to urban areas which often results primarily in a growing pool of urban unemployment. After experiencing similar tendencies in the early period of their planned development, the Chinese undertook deliberately and successfully to stem the pro-urban tide and to promote a balance between rural and urban areas. This required not merely increases in the allocations of public expenditure to rural areas and improvements in the terms of trade for agricultural goods, but also several more strongly interven- 
tionist policies: strict control of migration patterns so as to reverse the typical urban influx, the hsia-fang program of assigning urban school graduates to work for varying periods of time in rural areas, and the promotion of rural industrialization to bring jobs to the peasantry. Thus the usual pattern of cumulative imbalance between rural and urban areas was broken at several points.

The pro-urban bias in most third world nations has been criticized for its inefficiency as well as its inequity. ${ }^{18} \mathrm{It}$ is inefficient because it leads to the use of resources in urban areas which could be more productively used in rural areas, and it is inequitable because it favors urban over rural residents and often (as a consequence) richer over poorer people. By overcoming the conventional bias, the Chinese would appear to have reaped benefits both with respect to economic growth and with respect to national and regional economic equity. Moreover, by promoting the flow of resources, skilled personnel, and productive activities from urban to rural areas, the Chinese have also encouraged the growth of local self-reliance.

10. Limitation of the Role of Foreigners. The Chinese under Mao's leadership restricted sharply foreign involvement in the domestic economy as well as contact between the indigenous people and foreigners. Foreign trade was limited to critical imported commodities, and every effort was made to develop a domestic capacity to produce as wide a range of needed products as possible. Foreign ownership of productive assets was prohibited, foreign loans were sought in limited amounts and repaid as quickly as possible, foreign technical assistance was welcomed only when it was indispensible and contributed to the development of indigenous capacities, and foreigners were prevented from using their financial or technical inputs to develop bases of continuing economic power. Soviet financial and technical assistance played a critical role in Chinese industrial development in the first decade following the Revolution, but thereafter China did without significant external assistance from any source. At the same time, the Chinese people were kept isolated from the outside world by a virtual ban on foreign travel and strict limitation and regulation of visitors and communications from abroad.

This careful restriction of foreign involvement in the economy has obviously contributed to the achievement of greater self-reliance at the national level, both in economic self-sufficiency and national autonomy. It has encouraged the development of indigenous Chinese skills, resources, and technology, and has prevented foreign nations, agencies, or corporations from gaining significant economic power in China. Arguably, 
China might have been able to generate a more rapid rate of economic growth, at least in the short-run, by encouraging more foreign trade and seeking more foreign aid, loans, and technical assistance. But the Chinese experience suggests that vigorous determination to "do it yourself" by substituting indigenous initiative for foreign inputs can lead to an expansion and - even more important - a diversification of indigenous resources which gives the economy a greater adaptability to changing economic needs and to promote long-run economic growth. The advantages of self-reliance for long-run growth are especially important for technological ability, for it is well recognized that the kinds of technology appropriate for a poor (and especially a labor-abundant) economy are often very different than the technology available from foreign sources. ${ }^{19}$

\section{The Political-Economic Basis of the Chinese Strategy of Development}

The various elements of the Chinese strategy of development previously discussed were carried out in the context of the particular political-economic system introduced into China following the revolutionary triumph of the Chinese Communist Party in 1949. In assessing the relevance of the Chinese experience for other third world nations, one must first analyze the extent to which the Chinese strategy was linked to China's underlying political-economic system and the extent to which elements of that strategy could be pursued under different political-economic conditions. A political-economic system can be broadly characterized in terms of its basic economic institutions, the nature and strength of its state, and its class structure. Without trying to include all of the distinctive characteristics of the Chinese system, one can identify several essential features that can be shown to have contributed in one way or another to the successful implementation of the Chinese strategy of development. ${ }^{20}$

Two basic economic institutions were central to the Chinese political-economic system. First, there was predominantly public ownership and control of the means of production. Public control in China was exercised at a variety of levels and in a variety of forms, ranging from central government control of certain major industries to provincial, county, and municipal control of many smaller-scale industries to communal and sub-communal control of most agricultural activities; there was also cooperative control of some small services. Second, there was widespread administrative control of resource allocation. To a substantial degree (which has varied over time) the Chinese rejected the use of market-based prices and substituted administrative processes for allocating resources - 
notably in labor markets, markets for raw materials and intermediate goods, and markets for certain basic consumer goods. The necessary planning process was relatively decentralized, with administrative control exercised at many different levels of government.

The state - or governmental apparatus - in the Chinese political-economic system provided the national political leadership with great authority. First, the central government had the power to mobilize resources on a large scale for purposes determined by the national leadership. Through direct control of certain major public enterprises and its ability to tax other enterprises and activities, the central government acquired the purchasing power needed for substantial public expenditures; moreover, the leadership indirectly shaped the pattern of resource mobilization and expenditure at lower levels of government. Second, the Chinese system included an effective and extensive structure of public administration, which ensured that basic policy decisions of the national political leadership were carried out throughout the country and not frustrated at lower levels. This administrative structure involved not only the various levels of civilian government, but also (for various purposes) the army and the Communist Party. Moreover, it did not rely heavily on direct centralized control but instead permitted substantial lower-level operational autonomy in achieving goals established at the top. Third, a distinctive source of leadership authority in China was the ability to influence and involve people throughout the country in a profound way. This ability was attributable to several factors: the existence of an experienced and disciplined Communist Party organization, whose numerous cadres retained close ties with the masses; tight central control of educational institutions and the communications media; and the systematic development and dissemination of a purposeful ideology.

The class structure that has characterized China since the Revolution is complex and in many ways continuously evolving. Obviously the precapitalist and capitalist elites of the ancien regime - landlords, warlords, merchants, businessmen, etc. - ceased to play a significant role. In their stead, peasants, workers, soldiers, Party cadres and government officials occupied the stage. There is clearly a sense in which the Communist Party leadership can be considered an elite class in the People's Republic, since it occupies a position of great presitge and power. What is most relevant to the present analysis, however, is which class or classes can most successfully assure favorable consideration from the political leadership whether it be because of the social origin, the historical background, the need for ideological legitimacy, or any other characteristic of the leaders. 
In other words, the class orientation of the political leadership reflects in a significant way the underlying class structure of the Chinese politicaleconomic system.

Two main features of the class orientation of China's political leadership during Mao's lifetime stand out as particularly distinctive and important. First, the Chinese leaderhsip was strongly mass-oriented, as opposed to elite-oriented. For historical and ideological reasons, the Chinese Communist Party maintained a real commitment to the masses - poor peasants and workers - rather than orienting itself mainly to the interest of the elites - managers and intellectuals. Thus, significantly, the poor were in command in China. Second, the Chinese leadership was relatively rural-oriented rather than urban-oriented. The historical roots of the revolutionary success of the Chinese Communist Party, and the social origin of most Party members, were in the rural areas of the country; as a consequence, rural classes in general, and the peasants in particular, occupied an influential position in the overall class structure.

The political-economic system that was established in revolutionary China contrasts sharply with systems existing in most other nations of the third world. ${ }^{21}$ Some of these nations share one or more of the seven distinctive features of the Chinese system underlined in the preceding paragraphs, but very few share them all. Most contemporary third world nations are characterized by widespread private ownership of the means of production, considerable use of market price mechanisms for resource allocation, relatively weak structures of government authority, and class structures dominated by a mixture of pre-capitalist and capitalist elites. To investigate the extent to which lessons from the Chinese strategy of development might be applicable to nations with different politicaleconomic characteristics, I will consider in turn each of the ten major elements of the Chinese strategy and attempt to determine which of the distinctive features of the Chinese political-economic system were essential for their successful implementation.

The promotion of collective institutions and behavior patterns clearly presupposed the establishment of public ownership of the means of production, for private ownership implies control from the top and separates sharply the role of managers and workers. Public ownership is a necessary but by no means sufficient condition for the establishment of collective forms of work organization; indeed, most public enterprises in both capitalist and socialist economies are operated along conventionally authoritarian lines. To ensure that public enterprises are not dominated by 
bureaucratic managers and professional experts, it is also necessary that the class structure be oriented to the masses rather than to the elites. The ability of the Chinese to make a success of the major institutional and behavioral transformation involved in promoting collectivization clearly also depended on the strength of the Chinese state. In particular, an effective and extensive system of public administration would appear to be indispensable for thoroughgoing institutional reorganization, and the ability to reach, influence, and involve people on a large scale would seem essential for developing new patterns of behavior appropriate to the new institutions. The importance of involving people at the local level cannot be overstated, for unless the masses are sufficiently motivated it is all too easy for institutional change to be subverted by sullen hostility or uncooperative behavior.

The maximization of productive labor input was also dependent for its success on several major features of China's political-economic system. To raise the demand for labor the Chinese relied on administrative control of the allocation of labor as well as public control of most productive activities. These two basic economic institutions are not, however, indispensable for the purpose of promoting full employment. Profit-maximizing capitalists operating in a free labor market would surely not employ everyone in a labor-abundant economy where full employment would reduce the marginal contribution of labor to output well below a minimum acceptable subsistence wage. But it would be theoretically possible for capitalist government to raise the demand for labor sufficiently by some combination of wage subsidies (to reduce the cost of labor to private employers) and public job provision by the government as employer of last resort. Both this and the Chinese method, however, calls for a state with both the power to mobilize resources on a large scale and an effective structure of public administration. And a considerable degree of influence by the masses on the national leadership would most probably be required to make any kind of full employment strategy politically feasible.

To raise the supply of labor without significantly raising its cost and lowering its quality would appear to call for the use of non-market controls and incentives. The success of the Chinese in this respect depended significantly on administrative control of labor allocation and on effective public administration. Furthermore, the mass campaigns, large-scale work projects, and extra hours that were critical to increasing the supply of labor in China could not have been successfully promoted without the kind of ideological appeal to the masses and the organizational skills of 
Communist Party cadres that enabled China's political leadership to influence and involve people on a large scale.

The use of alternative means of work motivation involved major institutional and behavioral changes conceivable only in a system based on public ownership and control of the means of production. Collective gain incentives can be effective only where meaningful collective institutions exist in the first place; this calls for all of the political-economic conditions discussed earlier in the promotion of collective institutions and behavior. The successful use of non-material gain incentives requires in particular the identification of personal with societal interests; this is impossible to sustain for a long period of time unless the political leadership is oriented to the masses rather than identified with elites, and very difficult unless the political leadership can influence and involve people in a meaningful way. Finally, to the extent that individual material gain incentives are de-emphasized, wage differentials lose their allocative power and it becomes more likely - if not strictly necessary - that the labor market be subject to administrative controls.

The promotion of mass-oriented human resource development was not so heavily dependent on China's political-economic system as the other elements of China's development strategy. This is because human resource development is largely undertaken in public institutions (e.g., the educational system) no matter what the prevailing form of the basic economic institutions of a society. Thus one can conceive of a mass-oriented pattern of skill distribution in a system involving a major role for private enterprise and market price mechanisms. However, such a system would have to include a government with the power to mobilize resources on a substantial scale, so as to permit it to establish the necessary public institutions. Even more critical is that the class structure be sufficiently mass-oriented so as to prevent the demands of privileged elites (as consumers of services provided by skilled labor, or as acquirers of skills in the educational system) from fostering an elitist pattern of skill distribution.

The universal guarantee of material security required some but not all of the major political-economic features of contemporary China. A strong state with the power to mobilize resources on a large scale, with the ability to administer effectively an extensive distributional network, is clearly needed to distribute the benefits necessary to provide universal economic security. In addition, a significant amount of administrative control of resource allocation is likely to be necessary in a poor country to assure 
that essential but relatively scarce consumer goods are distributed in adequate amounts to everyone rather than captured disproportionately by the relatively better-off classes using their purchasing power in consumer good markets. Public ownership of the means of production would not appear to be essential, although it could facilitate the raising of necessary resources by public authorities as compared with the alternative of taxing private enterprise. Finally, the political leadership would have to be sufficiently mass-oriented so that elite classes could not prevent the substantial income redistribution implicit in a guarantee of an adequate real income floor to everyone within a relatively poor country.

The restriction of luxury consumption was probably the element of Chinese development strategy least tightly linked to China's political-economic system. The one critical feature of China's system indispensible to the successful application of this element of strategy would appear to be a mass-oriented class structure, for the restriction of luxury consumption clearly reduces the privileges of the elite classes and would not be seriously pursued by an elite-oriented political leadership. In China the virtual elimination of luxury consumption was in fact accomplished largely by means of administrative controls on consumer good distribution and the development of publicly owned consumer goods industries. But with the requisite political will it would be quite possible for a government to curtail luxury consumption in private enterprise and market price mechanisms by the judicious use of taxes and tariffs, which would not place excessive demands on the structure of public administration. Only if the restriction of luxury consumption were to be carried to the point where it significantly reduced the individual material rewards available to top-level executives, professionals, and administrators would it require a transformation of basic economic institutions so as to make use of alternative kinds of work incentives.

The reduction of the social division of labor opposes a powerful tendency of a private enterprise market-oriented economy and is therefore hard to conceive of without public ownership of the means of production and a substantial degree of administrative control over the labor market. Only where private capitalist control of the workplace has been eliminated can one envisage significant alternation of individuals among mental and manual tasks and across very different kinds of productive activities. And only where the training and allocation of labor is systematically planned rather than being left to the push and pull of market wages can one expect significant diversification and occupational rotation among workers. Whenever considerable reliance is placed on administrative control 
of allocational processes, an effective and extensive system of public administration also becomes essential to the success of the effort. And when the element of strategy calls for substantial change in patterns of behavior, as is clearly the case with reduction of the social division of labor, the ability of the political leadership to influence and to involve people becomes an essential political-economic requisite as well. Finally, the political feasibility of this element of strategy depends on the mass orientation of the class structure, for reducing the social division of labor undermines the privileged position of elites in the social order.

The encouragement of economic diversification of regions and localities clearly requires intervention by public authorities to counter the natural trend toward specialization that arises under laissez-faire capitalism. If private enterprise were left to itself, most major industries would be concentrated in areas where infrastructural facilities and other industries had already been developed the most fully; small-scale enterprises would often have a hard time competing with large firms and/or plants, and rural areas would attract very little industrial activity. Even a socialist economy might well develop along these lines if the primary concern of its leadership were to promote rapid industrialization in the short-run. Thus the features of China's political-economic system which were critical to the success of regional and local diversification were not its basic economic insitutions of public ownership and administered resource allocation. What was most essential was a class structure with a rural orientation and an effective and extensive system of public administration. A rural-oriented political leadership controlling an effective administrative apparatus might well be able to promote small-scale rural industrialization even within a predominantly capitalist economy, relying primarily on tax and subsidy policies to steer private enterprise away from its natural tendency toward industrial concentration and regional specialization.

The promotion of rural-urban balance in the development process also clearly calls for a political-economic system in which rural classes have a great deal of influence, and it too requires forceful intervention by public authorities against a natural market bias - in this case, a bias in favor of urban areas because they are almost always more economically advanced than rural areas. All too often in third world nations - whether capitalist or socialist - government intervention serves to exacerbate rather than to mitigate urban-rural differentials. Under the appropriate political-economic conditions the typical bias of public expenditures and price policies against rural areas could be overcome and possibly even turned in the 
opposite direction. This much would not appear to require either public ownership of the means of production or administrative control of resourceallocation. However, movement toward a genuine balance between rural and urban areas - such that economic opportunities and social welfare are equalized - calls for more than a change in government expenditure and price policies; usually a long history of pro-urban bias and urban advantage has to be overcome. To accomplish this the Chinese had to resort to policies (such as the direct control of migration patterns) that go well beyond the scope of government intervention into a basically capitalist economy and depend on a substantial degree of government administrative control of the labor market. And to ensure that enforced migration from urban to rural areas does not lead to so much discontent as to undermine seriously worker motivation and productivity, the ability of the political leadership to influence and involve people positively in such programs becomes very important. It is difficult to conceive of this combination of political-economic conditions without a substantial degree of public ownership of the means of production as well. Thus full implementation of a strategy of rural-urban balance would appear to require most of the major features of China's politicaleconomic system.

To limit the role of foreigners in a poor third world economy, in such a way as to promote rather than to retard long-run economic growth, the state must play a significant role. Not only must it formulate and implement various policies designed to curb foreign involvement and influence - e.g., controlling carefully the inflow of imports, foreign capital and foreign technology, limiting external debt, regulating foreign travel - but it must also undertake positive policies to make the best use of limited foreign inputs and to promote the use of indigenous resources and activities as a substitute for foreign ones. Thus a pre-condition for a strategy to promote self-reliance at the national level is a strong government, capable of mobilizing indigenous resources on a large scale and allocating them so as to minimize dependence on foreigners. Such a strategy needs an effective system of public administration.

Whether this element of China's development strategy required China's basic economic institutions and a mass-oriented class structure as well is debatable. In principle, an elite-oriented political leadership of a strong third world state could vigorously pursue nationalist policies within a capitalist economic environment to promote the interests of indigenous against foreign capitalists. In practice, however, capitalist economic institutions in the third world tend to be associated with a major foreign 
influence in the economy, and indigenous elites are often closely linked with foreign elites, because foreigners have historically played a major role in the development of capitalism in the third world, and indigenous elites have often depended on foreign support to maintain their power. ${ }^{22}$ Thus it would appear unlikely that most third world nations would or could successfully limit the role of foreigners in the economy without first having established a substantial degree of public ownership of the means of production (if not also administrative control of resource allocation), and without a class structure oriented more to the masses than to elites.

\section{The Significance of the Geographical and Historical Context}

Neither political-economic systems nor development strategies emerge from a vacuum. Underlying both aspects of the Chinese experience discussed in the preceding two sections are a geographical environment and an historical legacy that provided the context for the formulation and implementation of the Chinese development model. To assess the relevance of lessons from the Chinese experience for other third world nations, one must consider not only the extent to which the success of the Chinese strategy was rooted in the Chinese political-economic system, but also the way in which both the strategy and the system were linked to the underlying geographical and historical setting of modern China. In this section I will first identify some of the principal characteristics of China's geography and history, and then try to determine how significant a role they played in the success of the Chinese development experience. ${ }^{23}$

The first and most overwhelming geographic feature of modern China is its size. China is huge in both area and population; only two other nations have a larger surface area, and none has a higher population. Partly as a consequence of its large area, China is endowed with a considerable abundance and diversity of natural resources, and its high population contributes to a large internal market. Because much of the surface of China is mountainous or arid, the ratio of population to arable land is very high: the Chinese economy is decidedly land-scarce and laborabundant. One final important feature of China's geographical environment (in a broad sense) is the unusual degree of ethnological unity among its people; the dominant racial type, religious tradition, and written language is shared by close to $90 \%$ of the population.

The historical legacy of any modern nation is so rich and varied that it is difficult to single out a few particular characteristics for special attention. 
For the purposes of the analysis to follow, however, four elements of modern China's historical background seem most worthy of mention. The first is that the Chinese cultural heritage - including the values, attitudes, and behavior patterns of its people - was oriented to hard work in this life and in some ways favored cooperative over individualistic endeavor. Second, by the mid-twentieth century many Chinese had already had access to a practical education and had also had a substantial degree of experience with the administration of large and complex organizations. Although only a small elite received most of the education and undertook most of the administration, many more people did have some contact with (and developed some appreciation for) both activities. Third, China was spared the worst effects of the economic, political, and psychological onslaught of foreign domination. Imperialism - first Western and later Japanese - was an important force in Chinese history, but foreign powers did not intervene so forcefully in China as to wreck the whole socioeconomic structure and reorganize it in their own interests (as European colonists did in many other parts of the third world). Finally, and most obviously, modern China experienced a social revolution in the fullest sense of the term. The triumph of the Chinese Communist Party in 1949 marked a complete break with the past: a redistribution of economic and political power from one set of classes to another that completely transformed the class structure.

These major geographical and historical characteristics are as a group unique to China, although some of them are shared in varying degrees by other third world countries. No other third world nation is as large as China, but several have abundant and diversified resources as well as large internal markets, many third-world economies are labor-abundant, and some third world societies are ethnologically homogeneous. Just how critical this unique combination of geographic and historical conditions have really been for the success of the Chinese experience remains now to be considered. China's great size was clearly helpful for the implementation of a few of the elements of development strategy already discussed. The economic diversification of regions is easier to accomplish without loss of productive efficiency if the regions themselves have large internal markets, and limitations on the role of foreigners are more likely to succeed in promoting national economic self-reliance (in the sense of autonomy as well as self-sufficiency) simultaneously with economic growth if a nation has a large internal market and a diversified endowment of natural resources. Indeed, the promotion of a high degree of national selfsufficiency makes little economic sense for a small nation, for the costs of producing many kinds of goods would far exceed the costs of trading for 
them. Thus large size is probably helpful for promoting national economic autonomy (without sacrificing long-run growth), but it is surely essential for promoting national economic self-sufficiency.

Large size is not an unmixed blessing, for it can make the application of some elements of China's development strategy more difficult. The larger the surface area of the country, the more difficult it is to establish transportation and communication networks, and the larger the population, the more difficult it is to carry out administrative, organizational, and inspirational tasks. This implies that all of the elements of strategy depending significantly on the role of the state and the effectiveness of the political leadership are handicapped by large size. Most especially, the ability to mount an effective and extensive system of public administration, and the ability to influence and involve people on a wide scale, are rendered increasingly difficult the larger the size of the country; one or both of these two political-economic conditions were critical for the success of eight of the ten key elements of China's strategy of development (all but mass-oriented human resource development and the restriction of luxury consumption).

China's ability to overcome the handicap of size in developing a strong and effective state apparatus can be attributed in part to its high degree of ethnological unity. This relative unity - which extends from race to religion to written language and to many other elements of culture - makes it easier for the political leadership to maintain contact with all the people and to gain their respect and cooperation. It is especially important in promoting the identification of personal with societal interests, which is crucial for the success of non-material means of work motivation. By contrast, the many third world nations characterized by sharp ethnological cleavages face a much more difficult task in building a strong state whose legitimacy and power is widely respected.

The abundance of labor relative to land would appear to pose more of an obstacle than an aid to the execution of Chinese development strategy. To be sure, the abundance of labor does assure a high payoff to any strategy that succeeds in maximizing the use and effectiveness of labor as a productive resource. But it renders all the more difficult the generation of sufficient employment opportunities for every able-bodied person. Furthermore, the relative scarcity of arable land implies that agricultural output per acre must have already reached a fairly high level (to feed the population), which in turn implies that there remain few easy methods of increasing agricultural output (e.g., by bringing new land under cultiva- 
tion). Instead, increases in agricultural output are heavily dependent on institutional and/or technological changes that can raise the productivity of the available cropped acreage.

While the geographic setting of modern China offered a mixture of advantages and disadvantages for the successful application of Chinese development strategy, China's historical background was more unambiguously favorable. A cultural tradition that tends to value cooperation in fulfilling social responsibilities more than competition in achieving individual objectives is clearly conducive to the success of those elements of development strategy relying on collective modes of operation - notably, the promotion of collective institutions and behavior patterns, and the use of alternative means of work motivation. China's cultural tradition may also have aided the process of labor input maximization by facilitating the successful organization of large public works projects and mass work campaigns. China's heritage of educational and administrative experience no doubt contributed in some degree to the successful establishment of those basic economic institutions - public ownership of the means of production and administrative control of resource allocation - that depend for their success on the compentence of public authorities. ${ }^{24}$ This heritage must also have helped in the development of a strong state apparatus in general, and an effective administrative system in particular. One or more of these features of China's political-economic system were shown to be essential for the successful implementation of each of the ten key elements of China's strategy of development. A third world nation whose people had little educational or administrative experience to draw upon could eventually develop the requisite abilities, but it would be difficult for some time to make a success of any element of the Chinese strategy of development.

The fact that China had not been completely overwhelmed by Western imperialism by the mid-twentieth century had several important implications for the development potential of the society. First, most of the agrarian sector of the economy was still oriented to production for local needs rather than production of cash crops for export, and the domination of rural areas by urban interests was limited. Second, the individualistic and consumeristic ethos of modern capitalism had not pervaded the whole society: its impact was confined largely to certain urban and coastal areas. Third, the psychological state of self-doubt and exaggerated dependence on the foreigner, often induced by protracted periods of foreign rule and domination, ${ }^{25}$ was not widely imparted to the Chinese people. As a consequence, several elements of the Chinese strategy of 
development were rendered more effective. The promotion of regional and local diversification as well as rural-urban balance did not have to compensate for a protracted period of extreme specialization and urban domination. The promotion of collective institutions and behavior patterns as well as non-individual-material-gain incentives did not have to overcome a pronounced and widespread individualism. The restriction of luxury consumption did not have to contend with widespread emulation of more affluent foreign living standards. And the limitation of the role of foreigners could draw on indigenous price and self-confidence rather than foundering on misplaced deference to foreign skills and techniques.

The final critical element in China's historical background was the Communist Revolution itself. Needless to say, this profound social revolution was indispensable for the overthrow of the elite classes of the ancien regime, and it was directly responsible for generating a mass-oriented and rural-oriented class structure in post-revolutionary China. The extent to which the revolutionary movement (over a period of several decades) had been rooted in the masses in general, and the rural poor in particular, cannot be over-emphasized. For it is this mass and rural basis of the Chinese revolution that conditioned the orientation of the political leadership and molded the distinctive character of the Chinese class structure after 1949, and it also contributed significantly to the subsequent ability of the Chinese political leadership to influence and involve people on a wide scale in all kinds of development activities. Thus the revolution was directly responsible for three critical features of the Chinese politicaleconomic system. At least one of the three is essential for each of the ten key elements of China's development strategy, and all three contributed significantly to the environment in which China's political-system could be constructed. Theoretically, a mass-oriented and a rural-oriented political leadership could arise through evolutionary rather than revolutionary processes, and political leaders could develop means of influencing and involving people without the common experience of a revolutionary struggle. A long world history of fierce resistance by privileged classes to any substantial diminution of their power, however, suggests that an evolutionary transformation of class structure must be the exception rather than the rule.

\section{Conclusion}

If the ten elements of Chinese development strategy discussed earlier are to provide object lessons relevant for other third world nations, they must 
be potentially transferable to other societies. The extent to which each element of the strategy is transferable depends on the conditions under which it can be successfully implemented, and on the degree to which these conditions are satisfied in other third world nations. I had also sought to determine what political-economic, geographical, and historical conditions are required for the successful implementation of each of the ten elements of strategy. The results of this analysis are summarized in the form of a matrix in Table 1. Each of the ten elements of strategy under discussion requires at least one - and often many more - of the major features of China's political-economic system. In all cases an effective and extensive system of public administration and/or a massoriented class structure are required, and in most cases a considerable degree of public ownership of the means of production and administrative control of resource allocation is either necessary or helpful. Less often required, but crucial in a few cases, are a central government with the power to mobilize resources on a large scale, a political leadership capable of influencing and involving people on a wide scale, and a ruraloriented class structure.

Among the key geographic characteristics considered, large size is necessary or helpful for the successful implementation of two of the ten elements of strategy, but is disadvantageous in many cases because it is then more difficult for the political leadership to establish an effective system of public administration and to influence and involve people on a wide scale. An abundance of labor and scarcity of land is quite generally disadvantageous because it makes the achievement of rapid economic growth more difficult under any development strategy. But ethnological unity can be very helpful for the establishment of a strong state in all three respects $I$ have distinguished.

A cultural tradition oriented to cooperative work is quite helpful - if not strictly necessary - for three of the elements of strategy. A heritage of educational and administrative experience is helpful - but not absolutely essential - for all ten elements, since it improves the operation of those basic economic institutions and those characteristics of the state which have played an important role in the success of the Chinese development strategy. The less a society has been subject to foreign domination, the more its environment is likely to be conducive to the success of many elements of the Chinese strategy. And, finally, a profound social revolution would appear to be necessary in most instances for the development of three features of the Chinese political-economic system which as a group are indispensable for the success of all ten elements of the Chinese development strategy. 
These conclusions suggest that most of the elements of strategy described are currently applicable in only a few third world nations at best. Only a handful of nations have experienced a social revolution of any kind, and not all of these revolutions have been strongly rooted in the rural masses. Moreover, many of the revolutionary societies (e.g., Cuba, Mozambique, Vietnam) have a bitter history of Western imperialist domination to overcome, and most have only a limited heritage of educational and administrative experience to draw upon (e.g., the African nations). Some do not have a cultural tradition conducive to collective modes of operation (most notably Cuba), and many are ethnologically heterogeneous (e.g., Angola, Mozambique). Of all contemporary third world nations, North Korea would appear to come closest to meeting the historical, geographical, and political-economic conditions that have played a significant (and in many cases an essential) role in the success of the Chinese development strategy. But even in the case of North Korea the match is far from perfect in many respects.

Do these observations imply that the Chinese experience is essentially unique and therefore largely irrelevant for the rest of the third world? I think not. First of all, the Chinese experience has set new and higher standards for the evaluation of development performance and policy throughout the world: it is no longer enough to promote rapid economic growth, but development planners can and will be held accountable for achieving a balanced pattern of development in which non-growth objectives such as greater equity and self-reliance are promoted along with faster growth.

Second, certain elements of the Chinese development strategy do lend themselves to successful application - at least to a certain extent - in other societies which differ considerably from China in their politicaleconomic, geographical, and historical conditions. For example, the promotion of mass-oriented human resource development could be carried out with some success in a nation with a reasonably strong state (in terms of its capacity for resource mobilization and public administration) and a political leadership somewhat oriented to the masses. A strategy of restriction of luxury consumption is potentially more widely transferable, for it requires mainly a mass-oriented political leadership and, up to a point, does not depend on an unusually effective state apparatus. Some degree of economic diversification of regions and localities, as well as some degree of amelioration of rural-urban imbalance, can be successfully accomplished provided that the political leadership is sufficiently rural-oriented and can rely upon an effective and extensive administra- 
tive system. In all these cases the necessary configuration of political-economic conditions is possible (if not very likely) in a society that has not undergone a profound social revolution and that operates within a predominantly capitalist institutional framework. More revolutionary change would be more conducive to success, but not absolutely essential for some progress to be made.

Third, and more important, some of the key conditions required for the successful implementation of much of the Chinese development strategy can be realized in the future even if they do not obtain at present in most third world societies. Here it is important to distinguish between those aspects of the setting of any given society which are virtually immutable and those aspects which are amenable to change under appropriate historical circumstances. The key geographical characteristics that I have discussed clearly involve stable features of a society's environment; nothing short of massive territorial annexation, massive migration, or genocide could alter the size, the resource endowment, or the ethnological structure of contemporary third world nations. The historical characteristics I have cited vary considerably in their susceptibility to change. Cultural traditions built up over centuries (and in some cases millenia) cannot be transformed within a generation. The amount of time it takes to overcome the effects of Western imperialism depends of course on the force and the longevity of its imposition, but in many areas at least a generation might be needed. And a substantial degree of educational and administrative experience can only be built up with several decades of concerted effort. The possibility of significant change in any of these three historical characteristics hinges on some kind of decisive break with the past which ushers in new political leadership determined to bring about large-scale change. Such a decisive break need not involve a revolutionary redistribution of power from dominating to oppressed classes, but it does require at least the accession to power of strongly nationalist forces determined to "modernize" their country (i.e., to increase its resemblance to the powerful industrialized nations of the modern world).

Social revolution is the most fundamental historical characteristic of all, for it underlies the establishment of many of the key features of China's political-economic system and (not incidentally) also creates a context in which the needed changes in the other three historical characteristics become more readily achievable. Profound social revolutions, in which formerly oppressed classes do succeed in wresting power from formerly privileged classes, are not made overnight, but they can be brought about after a period of revolutionary organization and struggle. If the revolution- 
ary movement is to be truly rooted in the masses (and the rural masses in particular), and if it is to succeed in a contemporary international context in which privileged classes in third world nations can often count on support from major foreign powers, it is bound to take a great deal of time and effort. But the point I am making here is that it has been done in some countries in the past, and there is every likelihood that it will eventually be done in some other countries in the future.

At present it would be foolhardy to attempt to predict where Chinese-style revolutions might succeed in generating historical and political-economic conditions approximating those which have contributed to the success of the Chinese strategy of development. But there are many third world nations with one or more relevant geographic and historical characteristics already similar to China's. For example, India, Indonesia, and Brazil share China's large size, some of the Latin American nations are ethnologically quite homogeneous, many East and Southeast Asian nations have cultural traditions resembling those of the Chinese, the people of India and some of the other semi-industrialized nations of the third world have already acquired a substantial degree of educational and administrative skills, and nations such as Tanzania, Ethiopia, and Afghanistan were not thoroughly restructured by foreign powers. Profound social revolutions in any of these nations - however distant the prospect may now appear - would go a long way toward establishing the conditions under which many of the lessons from the Chinese strategy of development could indeed be successfully applied. As for the immediate future, there is little likelihood that the Chinese experience will be of much relevance to development planning in the rest of the third world. For the great majority of third world nations are still dominated by propertied or otherwise privileged elites, and, as one observer has put it, "revolution is precisely the fate which [they] are striving to avert through their development."26

\section{Acknowledgment}

A preliminary version of this paper was presented at a panel entitled "The People's Republic of China and the Third World," held at the 30th International Congress of Human Sciences in Asia and North Africa in Mexico City on August 3-8, 1976. I am grateful to Samuel Bowles, Robert Dernberger, and an anonymous referee for their constructive comments on my work. 
TABLE 1

\begin{tabular}{|c|c|c|c|c|c|c|c|c|c|c|c|c|c|}
\hline $\begin{array}{l}\text { Political-Economic, } \\
\text { geographical, } \\
\text { and historical } \\
\text { conditions }\end{array}$ & 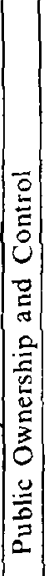 & 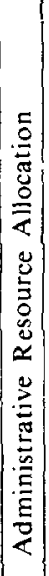 & $\mid$\begin{tabular}{l} 
\\
0 \\
0 \\
0 \\
0 \\
0 \\
0 \\
0 \\
$\simeq$ \\
0 \\
0 \\
\hdashline \\
0 \\
0 \\
0 \\
$\Sigma$ \\
0 \\
2 \\
0 \\
0 \\
0 \\
0 \\
0 \\
0
\end{tabular} & 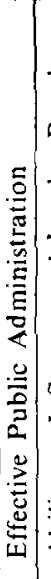 & 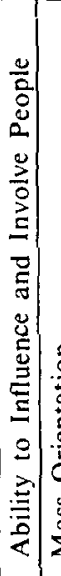 & $\mid$ & 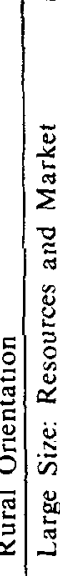 & 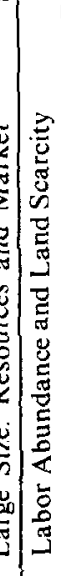 & 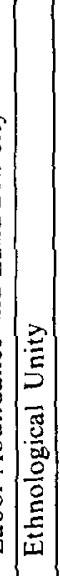 & 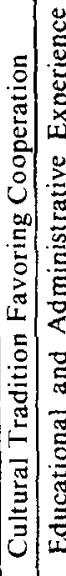 & 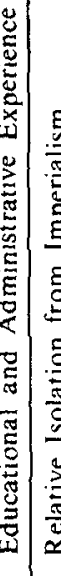 & 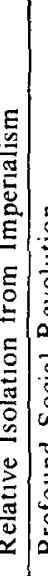 & 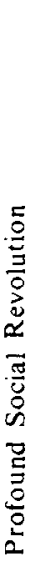 \\
\hline $\begin{array}{l}\text { Collective Institutions } \\
\text { and Behavior }\end{array}$ & $\mathrm{N}$ & & & $\mathrm{N}$ & $\mathrm{N}$ & $\mathrm{N}$ & & D $D$ & $\mathrm{H}$ & H $\mathrm{H}$ & $\mathrm{H} / \mathrm{H}$ & $\mathrm{H} / \mathrm{H}$ & $\mathrm{H}$ \\
\hline $\begin{array}{l}\text { Maximization of } \\
\text { Labor Input }\end{array}$ & $\mathbf{H}$ & $\mathbf{N}$ & $\mathrm{N}$ & $\mathbf{N} \mid$ & $\mathbf{N}$ & $\mathrm{H}$ & & $D \mid D$ & $\mathbf{H}$ & $\mathrm{H}$ & $\mathrm{H}$ & & $\mathrm{H}$ \\
\hline $\begin{array}{l}\text { Alternative Means } \\
\text { of Work Motivation }\end{array}$ & $\mathrm{N}$ & $\mathrm{H}$ & & $\mathrm{N}$ & $\mathbf{N}$ & $\mathrm{N}$ & & $\mathrm{D} \mid \mathrm{D}$ & $\mathrm{H}$ & $\mathbf{H}$ & $\mathrm{H} \mid \mathrm{H}$ & H & $\mathbf{H}$ \\
\hline $\begin{array}{l}\text { Mass-Oriented Human } \\
\text { Resource Development }\end{array}$ & & & $\mathrm{N}$ & & & $\mathbf{N}$ & & D & $H$ & & H) & & $\mathrm{H}$ \\
\hline $\begin{array}{l}\text { Universal Guarantee } \\
\text { of Material Security }\end{array}$ & & $\mathrm{H}$ & $\mathrm{N}$ & $\mathrm{N}$ & & $\mathbf{N}$ & & D $D$ & $\mathrm{H}$ & & $\mathrm{H}$ & & H \\
\hline $\begin{array}{l}\text { Restriction of } \\
\text { Luxury Consumption }\end{array}$ & & & & & & $\mathbf{N}$ & & D & & $\mathrm{H} / \mathrm{H}$ & $\mathrm{H} / \mathrm{H}$ & $\mathrm{H}$ & \\
\hline $\begin{array}{l}\text { Reduction of the } \\
\text { Social Division of Labor }\end{array}$ & $\mathrm{N}$ & $\mathrm{N}$ & & $\mathrm{N}$ & $\mathbf{N}$ & $\mathrm{N}$ & & $D$ & $H$ & & H & & $\mathrm{H}$ \\
\hline $\begin{array}{l}\text { Diversification of } \\
\text { Regions and Localities }\end{array}$ & & & & $\mathrm{N}$ & & & \begin{tabular}{l|l}
$N$ & $H$
\end{tabular} & $H$ D & $\mathrm{H}$ & & $\mathrm{H} \mid \mathrm{H}$ & \begin{tabular}{l|l}
$\mathrm{H}$ & $\mathrm{H}$
\end{tabular} & H \\
\hline Rural-Urban Balance & $\mathbf{H}$ & $\mathrm{N}$ & & $\mathbf{N}$ & $\mathrm{N}$ & & $N$ D & $\mathrm{D} \mid \mathrm{D}$ & $H$ & & \begin{tabular}{l|l}
$H$ & $H$
\end{tabular} & $\mathrm{H}$ & H \\
\hline $\begin{array}{l}\text { Limitation of the } \\
\text { Role of Foreigners }\end{array}$ & $\mathrm{H}$ & & $\mathrm{N}$ & $\mathbf{N}$ & & $\mathrm{H}$ & & $\mathbf{N} \mid \mathbf{D}$ & $H$ & & $\mathrm{H} \mid \mathrm{H}$ & $\mathbf{H}$ & H \\
\hline
\end{tabular}




\section{NOTES}

1. Basic data on rates of economic growth in China since 1949 - on an aggregate, sectoral, and per capita basis - are presented by Arthur G. Ashbrook, Jr., in his contributions to the following two volumes: People's Republic of China: An Economic Assessment and China: A Reassessment of The Economy; published by the Joint Economic Committee of the U.S. Congress in 1972 and 1975, respectively. Other articles in each of these volumes provide more detailed information on the performance of different sectors of the Chinese economy. For an excellent summary of China's overall economic performance under Mao Ze-dong, see also Suzanne Paine, "Development With Growth: A Quarter Century of Socialist Transformation in China," Economic and Political Weekly (Bombay, India), Vol. 11, Nos. 31-33 (Special Number, August 1976). Paine performs a valuable service by examining carefully alternative estimates of China's economic growth and by exposing the downward bias that colors many Western appraisals of China's progress under Mao.

2. For comparative figures on economic growth in the third world since 1950, see Thomas E. Weisskopf, "Imperialism and the Economic Development of the Third World," in R. Edwards, M. Reich, and T. Weisskopf, eds., The Capitalist Sirstem (PrenticeHall: Englewood Cliffs, N.J.: 2nd edition, 1978).

3. A good summary of the evidence on trends in various dimensions of economic equity in China since the Revolution is provided by Paine, Part II; see also Alexander Eckstein, China's Economic Revolution (Cambridge: Cambridge University Press, 1977), pp. 298-304. Nicholas Lardy, in his Economic Growth and Distribution in China (Cambridge: Cambridge University Press, 1978), chapter 5, provides especially useful information on the Chinese effort to alleviate urban/rural and inter-regional disparities in living standards. The critical distinction between inequalities in money income and the consequences of those inequalities for people's life styles is stressed by Martin Whyte, "Inequality and Stratification in China," The China Quarterly', No. 64 (December 1975).

4. For a discussion of evidence on unemployment in China (compared to India), see Thomas E. Weisskopf, "China and India: A Comparative Survey of Performance in Economic Development," Economic and Political Weekll' (Bombay, India), Vol. 10, Nos. 5-7 (Annual Number, February 1975), section III.

5. The extent to which China has achieved economic self-reliance at the national level is discussed in Alexander Eckstein, pp. 309-311, and Thomas E. Weisskopf, section IV. There is considerably less information available on self-reliance at the regional and local levels, but some relevant evidence is discussed in articles by Roll and Yeh, Lardy and Sigurdson in China: A Reassessment of the Economy:

6. See Thomas E. Weisskopf, "Imperialism and the Economic Development of the Third World" and Michael P. Todaro, Economic Development in the Third World (London: Longman, 1977), chapter 2, for discussions of the evidence on this point.

7. The picture I have drawn here of China's development achievements is somewhat at variance with a revisionist view now emerging in the United States, to the effect that under Mao's leadership the Chinese accomplished no more - and perhaps even rather less - than many nonsocialist third world countries in the same period. Setting aside such dubious popular sources as Time (which revealed its own political orientation in crowning Deng Xiao-ping its "Man of the Year" for 1978), the new revisionist view of Mao's China is perhaps best exemplified by a three-part article by Nick Eberstadt in the New York Revien' of Books (Volume 26, Nos. 5-7: April 5, 19, and May 3, 1979), provocatively entitled "Has China Failed?" Much of Eberstadt's argument and documentation recalls the list compiled by Paine, page 1363, for the benefit of "the incorrigible China critic," of "short cuts which can be relied upon to produce the sort of implausibly low estimates of Chinese output which at times he seems to seek." Significantly, even after minimizing China's progress with respect to some important devel- 
opment goals, Eberstadt concludes that "What seems certain, however, is that the number of people at the margins of society fell dramatically in Maoist China. No other large country in the poor world - not India, not Indonesia. Bangladesh, or Pakistan, not even oil-rich Nigeria or industrialized Brazil can say the same." It is perhaps no coincidence that the revisionist attempt to downgrade China's achievements under Mao comes at a time of political and economic rapprochement between the US government and business elite and Mao's successor regime in China both of whose interests are now well served by minimizing the success and rejecting some of the key policies of the strategy of development pursued in China under Mao's leadership.

8. The ten elements of strategy that form the focus of this paper comprise what some observers have labelled the "Maoist" model as distinct from the "Soviet" model of socialist development strategy. Since 1949 the Chinese leadership has pursued policies associated with both of these models, sometimes following more of a Soviet path (in much of the 1950s) and sometimes following more of a Maoist path (in the late 1960s and early 1970s). The reason I have chosen to concentrate on the Maoist model here is that it appears (on theoretical grounds) to contain many more lessons than the Soviet model about how to promote multiple development objectives simultaneously. In keeping with its rejection of some key elements of the legacy of Mao, the Chinese political leadership in the post-Mao period has sought to discredit the Maoist model by arguing that it was detrimental to China's economic development. If this argument were correct, it would undermine my analysis of the lessons to be drawn from the Chinese strategy of development. In my view, however, the argument of the post-Mao leadership is highly suspect - in part because it reflects the typically exaggerated rhetoric of a high-level power struggle, and in part because it seems to be based on a redefinition of the term "economic development" to mean simply a very high rate of economic growth rather than substantial growth combined with significant progress toward other important development objectives.

9. Rather than burden the paper with footnotes documenting each separate element of strategy described in this section, I will cite here the main sources that I have relied upon for my whole discussion of the Chinese strategy of development: Stephen Andors, China's Industrial Revolution: Politics, Planning and Management, 1949 to the Present (New York: Pantheon, 1977); Alexander Eckstein; John G. Gurley, China's Economy and the Maoist Strateg.' (New York: Monthly Review Press, 1976); Nicholas Lardy; Barry M. Richman, Industrial Society in Communist China (New York: Random House, 1969); E. L. Wheelwright and Bruce McFarlane, The Chinese Road to Socialism (New York: Montly Review Press, 1970); and the two volumes published by the Joint Economic Committee of the U.S. Congress, cited in footnote 1.

10. The possibilities for increasing productivity by increasing worker participation in decision-making are now gaining recognition in the Western world; see, for example, Paul Blumberg, Industrial Democracy (New York: Schocken, 1969). It should be noted, however, that this approach can place heavy demands on people's time in meetings and discussions; the "labor-intensive" character of worker participation, and its particular suitability to a labor-abundant economy like China's, have been underlined by Donald Keesing, "Economic Lessons from China," Journal of Development Economics, Vol. 2, No. 1 (March 1975), p. 18.

11. See Carl"Riskin, "Maoism and Motivation: Work Incentives in China," Bulletin of Concerned Asia Scholars, Vol. 5, No. 1 (July 1973), for a particularly insightful discussion of the potential for productivity gains in improved worker motivation and an analysis of the alternative kinds of work incentives utilized in China.

12. This is the phrase used consistently by neoclassical economists to describe expenditures on education, health, etc., which tend to increase the productive and income-earning capacities of individuals.

13. For a graphic demonstration of this point, see Mahmood Mamdani, The Myth of Population Control (New York: Monthly Review Press, 1972). 
14. This point has been stressed by Gunnar Myrdal; see his Asian Drama (New York: Pantheon, 1968), Volume III, Appendix 2, section 21, pp. 1912-1919), for an instructive discussion.

15. This interesting and significant point has been made by Donald Keesing, p. 4. He compares the Chinese guarantee of material security on a societal level to an individual household's guarantee of security to each family member, and goes on to point out that "economists have recognized for some time that potential labor resources are more thoroughly used ... within an individual household (as in a family farm) than in a wage-paying enterprise bent on maximizing profits," for, unlike a family enterprise, "a capitalist enterprise has no incentive to use labor past the point where the marginal revenue product of the added work is at least equal to the wage; and the wage rate is unlikely to fall below the minimum needed for a subsistence income."

16. For evidence on this point, see J. Land and R. Soligo, "Consumption Patterns, Factor Usage and the Distribution of Income: A Review of Some Findings," mimeo., Program of Development Studies (Rice University, Houston, Texas, 1974).

17. Many of these benefits have been analyzed by Jon Sigurdson; see, for example, his paper on "Rural Industrialization in China: Approaches and Results," World Development. Vol. 3, Nos. 7-8 (July-August, 1975).

18. See Michael Lipton, Why Poor People Stay Poor (Cambridge, Mass.: Harvard University Press, 1977), for a detailed discussion of the pro-urban bias in most third world countries and the consequences of this bias for economic performance.

19. For a useful survey of the literature on the appropriate choice of techniques of production in poor countries, which stresses the importance of developing indigenous technological capabilities, see R. B. Sutcliffe, Industry and Underdevelopment (London: Addison-Wesley, 1971), chapter 5.

20. My characterization of the essential features of China's political-economic system draws on a variety of sources, including Alexander Eckstein; Jan S. Prybyla, The Political Economy of Communist China (Scranton: International Textbook Co., 1970); and Franz Schurmann, Ideology and Organization in Communist China (Berkeley: University of California Press, 2nd edition, 1968).

21. Political-economic conditions in many parts of the third world are described in Gunnar Myrdal, The Challenge of World Poverty (New York: Pantheon, 1970) and Charles K. Wilber, ed., The Political Economy of Development and Underdevelopment (New York: Random House, 1973).

22. Samir Amin, Unequal Development (New York: Monthly Review Press, 1976), analyzes from a Marxist perspective the historical development of capitalism in the third world.

23. My sources on the geographical and historical characteristics of the Chinese setting include Alexander Eckstein; Kenneth S. Latourette, China (Englewood Cliffs, N. J.: Prentice-Hall, 1964); Dwight Perkins, ed., China's Modern Economy in Historical Perspective (Stanford: Stanford University Press, 1975); and Franz Schurmann.

24. Dwight Perkins emphasizes this point in his essay, "The Central Features of China's Economic Development," in Robert F. Dernberger, ed., China's Development Experience and the Other Developing Countries (Cambridge, Mass.: Harvard University Press, 1979).

25. The debilitating psychological effects of foreign domination are analyzed (from opposing political perspectives) by $\mathrm{O}$. Mannoni, Prospero and Caliban: The Psycholog.' of Colonization (New York: Praeger, 1956) and Frantz Fanon, Black Skin. White Masks (New York: Grove Press, 1967).

26. The quote is from Neville Maxwell, in his introduction to a special issue, entitled "China's Road to Development," of World Development, Vol. 3, Nos. 7-8 (July-August 1975), p. 454.

Theory and Society 9 (1980) 283-318

(-) Elsevier Scientific Publishing Company, Amsterdam - Printed in the Netherlands. 